\title{
EFFECT OF CLIMATE CHANGES ON GROWTH PATTERN OF COTTON PLANTS IN RELATION TO THE INFESTATION WITH PINK BOLLWORM, PECTINOPHORA GOSSYPIELLA (SAUND.) IN SHARKIA GOVERNORATE, EGYPT
}

\author{
NADA, M. A. ${ }^{1}$; M. M. ABOU-SETTA ${ }^{1}$; A.A.A. EL- SAYED ${ }^{1}$, \\ M. G. RAGAB ${ }^{1}$ and M. K. HASSANEIN ${ }^{2}$
}

1. Plant Protection Research Institute, Dokki, Giza

2. Central Laboratory for Agricultural Climate, Dokki, Giza

(Manuscript received 1 July 2017)

\begin{abstract}
T he effect of future predicted temperature increase in 2025, 2050, 2075 and 2100 on four phenomena accumulated heat units (AcHU), infestation of cotton fruits with pink bollworm (PBW), Pectinophora gossypiella (Saund.), the growth patterns of cotton plants, Gossypium barbadense (L.) in five sowing dates related starting from March 10 to April 30, with 10 days intervals compared to the current seasons (CS) (1999-2002) were directed. The experiments were carried out at Sharkia Governorate for four cotton seasons (1999-2002) current seasons (CS). Results showed that the first phenomenon, during CS average of AcHU recorded 3814 unit, whereas in the predicted seasons it increased than the CS with 258 units in 2025 continued in increasing until reached to 715 units in 2100 season. The second phenomenon, occurrence of male moths fluctuated through CS and recorded four peaks for each season. Moth emergence of the first peak, overwintered as diapause larvae, depended on AcHU from fixed date, Jan., 1; occurred over the last third of May; while at the expected seasons occurred early abut month, over at the last third of April on 2100 season. The other three peaks depended on sowing dates. Whenever, delayed sowing date fruiting structures will be subjected for attack by peak of moth's emergence for short period of time. The third phenomenon, the period in days required for occurring 50 percent of fruit structures on cotton plants and occurring green cotton bolls preferred for infestation with PBW larvae, decreased at the expected seasons. The first dates of cultivation had been highly reduction but the fifth one was the lowest. The fourth phenomenon, in over the four expected cotton seasons, Julian days required for the five cotton sowing dates were short where reduction in days percentages ranged between 35.1 and $22.6 \%$ in 2100 cotton seasons comparing to average days in the four CS. The physiological time required for occurrence of these phenomena were decreased over the five sowing dates at the expected seasons, it cleared that the cotton plant and PBW can get the heat unit required in short time. Under climate change régimes, Agricultural lionizers should take into consideration, it will result in earliness in beginning cotton cultivation, growth of cotton pattern, the first peak of PBW moth's emergence, increase number of its generations. As for, planting dates, climate changes play an important role to suffer more damage or escape some damage depending on the actual response to climate changes.
\end{abstract}

Key words: pink bollworm, PBW, Pectinophora gossypiella, cotton plants, Gossypium barbadense (L.), current seasons, CS, accumulated heat unit AcHU. 


\section{INTRODUCTION}

Agriculture is an activity that is highly dependent on weather and climate to produce various life necessities for human. Natural plants and economic crops are distributed worldwide according to climate suitability and consistency. Therefore, agricultural crops are vulnerable to climate variability and change. Climate change is one of the determining factors for the strategic planning of agricultural crops in the near and far future. One of the economic crops in Egypt that could be affected by climate change is Cotton. Recent studies indicated that temperature rise favors cotton plant growth and productivity. Nevertheless, nothing was shown on the impact of such temperature on cotton major pests. Even if the overall effect of climate change might be negligible on global basis, regional impacts are likely to be substantial and variable, with some regions benefiting and others adversely affected. It is expected that most critical regions of the world (e.g. subtropical and tropical areas) will face great decline in food production, whereas agriculture in developed countries may actually benefit (Parry et al. (2004). Gutierrez et al., (2006) in Northward into the San Joaquin Valley mentioned that increasing temperatures, $1.5^{\circ} \mathrm{C}-2.5^{\circ} \mathrm{C}$, would greatly increase winter survival and extend the range of pink bollworm, Pectinophora gossypiella (Saund.),. Furthermore, damage levels would increase in PBW's current range in the southern desert valleys of California and in Arizona. The range of the pink bollworm is limited worldwide by winter frost; hence the predicted milder winters would increase its range Northward, into the San Joaquin Valley of California. Outbreaks of pink bollworm are predicted to be more frequent and severe. Global climatic changes are expected to have an impact on insect-plant interactions in several ways. They might affect insects directly, through changes in physiology, behavior and life history parameters, as well as indirectly, through changes experienced by host plants in their morphology (Barnes et al. 1988, Kádár and Szentkirályi 1997, Hennebry and Naranjo 1998, Venette and Hutchinson 1999, and Morrison and Morecroft 2006). Consequence of warming migrant moths, such as Helicoverpa armigera (Hub.) have also shown a "increasing phenomena" over the period 1969-2004, penetrating inland more frequently (Parsons and Davey 2007). Increasing winter temperatures have been proposed to be the key factor affecting range shifts in insects by reducing winter mortality (Ungerer et al. 1999, Veteli et al. 2005 and Battisti et al. 2005).

Cotton, Gossypium barbadense (L.), is a summer cash crop for its cotton fiber, seed oil and cotton oil-cake in Egypt. During its growing season, it is attacked by many pests. Pink bollworm, P. gossypiella, is considered a serious pest damaging 
cotton fruit structures and affecting yield significantly. Planting date, which is controlled by suitable weather conditions, is a vital element for PBW infestation. The effect of climate change on cotton production was more drastic in a hot and dry year. Since most of the days with average temperatures above $32.0^{\circ} \mathrm{C}$ will likely occur during the reproductive phase, irrigation will be needed to satisfy the high water demand, and this reduces boll abscission by lowering canopy temperatures. Cotton grows at temperatures ranging from a minimum of 12.0 to $15.0^{\circ} \mathrm{C}$ to an optimum of 26.0 to $28.0^{\circ} \mathrm{C}$, and the maximum plant-sustainable temperature depends on the duration of exposure (Reddy et al. 1997 and Reddy et al. 2002).

Balls (1919) reported that cotton in the field in Egypt seemed to grow best around $32.0^{\circ} \mathrm{C}$, and that prolonged temperatures above $35.0^{\circ} \mathrm{C}$ were harmful. An optimum temperature range of 20.0 to $30.0^{\circ} \mathrm{C}$ has been reported for cotton (Reddy et al, 1991). In contrary, cotton is successfully grown at temperatures in excess of $40^{\circ} \mathrm{C}$ in India and Pakistan (Burke and Wanjura, 2009). Sowing date of Cotton in Egypt varied from early March to early May, with different planting dates for each farm at the same village. As a result, fruiting structures (which is the target for PBW infestation) will be subjected for attack by overwintering PBW population for long period of time. PBW moths emerge from overwintering diapause larvae depending on accumulated heat units (Sawires, 1976, Aboiu-Zeid et al., 1989 and Eissa et al., 1989). The time of moth emergence differs in different locations under current climatic conditions and future climate changes.

In this study the effect of predicted temperature increase, due to global warming, on the relation between growth patterns of cotton plants and pink bollworm (BPW) infestation was investigated.

\section{MATERIALS AND METHODS}

The present study was carried out at Sharkyia Governorate during four cotton growing seasons (1999-2002). Because the sowing season of cotton in Egypt expands over two month's period, the selected experimental locations were represented by five sowing dates starting from March 10 to April 30, with 10 days intervals. Each selected location, of at least twenty Feddans of homogeneous sowing date, received conventional agricultural practices and chemical control program assigned by the Ministry of Agriculture and Land Reclamation (MALR). Five sampling areas $\left(500 \mathrm{~m}^{2}\right)$ were allocated in each location. Twenty cotton plants were randomly selected, from each sampling area, every six days. Cotton fruiting structures squares and boll numbers were counted on each plant.

Delta sticky traps, baited with gossyplure were fixed at the first week of 
March to monitor the pink bollworm, male moth numbers counted every three days. One trap was allocated to each location. Pheromone capsules were replaced by fresh ones every 15 days during the cotton season. Obtained data were used to show the relation between PBW activities and selected cotton plant structure over time. Earliest occurrence is identified as the date for earliest detection of fruiting structures liable for PBW development. These fruiting structures are suitable for larval development.

Daily maximum and minimum temperatures for the four years were obtained from the weather station located at Abu-kabeer Agricultural Research Station, ARC, at Sharkyia Governorate. The projected changes in air temperature under the Intergovernmental Panel on Climate Change (IPCC's) SRES scenarios; for the years 2025, 2050, 2075 and 2100; were obtained from the Central Laboratory for Agricultural Climate (CLAC), Dokki, Giza (Table 1). Heat units were calculated, from the $1^{\text {st. }}$ of January, for the four cotton seasons of 1999-2002, according to Seaver et al., (1990) (degree days calculated with base $30 / 12.78{ }^{\circ} \mathrm{C}$ ).

The average number of days and accumulated heat units, needed for the occurrence of each plant cotton fruiting structure and insect stage, for the four seasons, recorded in this study were used as the current data (observed data). These were compared with the predicted values previously obtained for the years 2025, 2050, 2075 and 2100. Table (1) shows future maximum and minimum temperatures for Sharkyia Governorate, Egypt, in 2025, 2050, 2075 and 2100 years according to (IPCC) are shown in Table (1). Ratios are multiplicative factors for the current weather.

Table 1 . The predicted increase rates of daily maximum and minimum temperatures for Sharkyia Governorate in 2025, 2050, 2075, and 2100 years according to IPCC.

\begin{tabular}{|c|c|c|c|c|c|c|c|c|c|c|c|c|c|c|}
\hline \multirow{2}{*}{$\begin{array}{c}\text { Predicted } \\
\text { years }\end{array}$} & \multicolumn{12}{|c|}{ Month(s) } & \multirow{2}{*}{ Average } & \multirow{2}{*}{$\mathrm{Sd}$} \\
\hline & Jan & Feb & Mar & Apr & May & Jun & Jul & Aug & Sep & Oct & Nov & Dec & & \\
\hline 2025 & 1 & 1 & 1 & 0.9 & 0.9 & 1.2 & 1.4 & 1 & 1.4 & 1.2 & 0.9 & 1 & 1.1 & 0.2 \\
\hline 2050 & 1.7 & 1.7 & 1.6 & 1.5 & 1.6 & 2.1 & 2.4 & 1.9 & 2.3 & 2.1 & 1.6 & 1.6 & 1.8 & 0.3 \\
\hline 2075 & 2.3 & 2.4 & 2.3 & 2.1 & 2.2 & 2.8 & 3.2 & 2.6 & 3.1 & 2.8 & 2.2 & 2.3 & 2.5 & 0.4 \\
\hline 2100 & 2.9 & 2.9 & 2.8 & 2.6 & 2.7 & 3.5 & 4 & 3.1 & 3.9 & 3.4 & 2.7 & 2.8 & 3.1 & 0.5 \\
\hline
\end{tabular}

\section{RESULTS}

Data in Figure (1) show the average number of accumulated heat units (AcHU's) from a fixed date, the first of January, to the end of December. The seasonal fluctuation of pink bollworm (PBW), male moths were illustrated from the beginning of its appearance in the sex pheromone baited traps at the first week of May to the first 
half of December during study seasons that extended from 1999-2002 cotton seasons. The AcHU's increased gradually from the fixed date to the end of December, which recorded 3814 unit. Occurrence of male moths fluctuated during the study seasons and recorded four peaks every season. Moth's emergence of the first peak, which overwintering as diapause larvae, had been affected by AcHU's from fixed date, temperature dependant. It occurred at the last third of May through the four study seasons. The other reminder three peaks their larvae developed in fruit cotton structures squares and green cotton bolls, cotton sowing dates dependent.

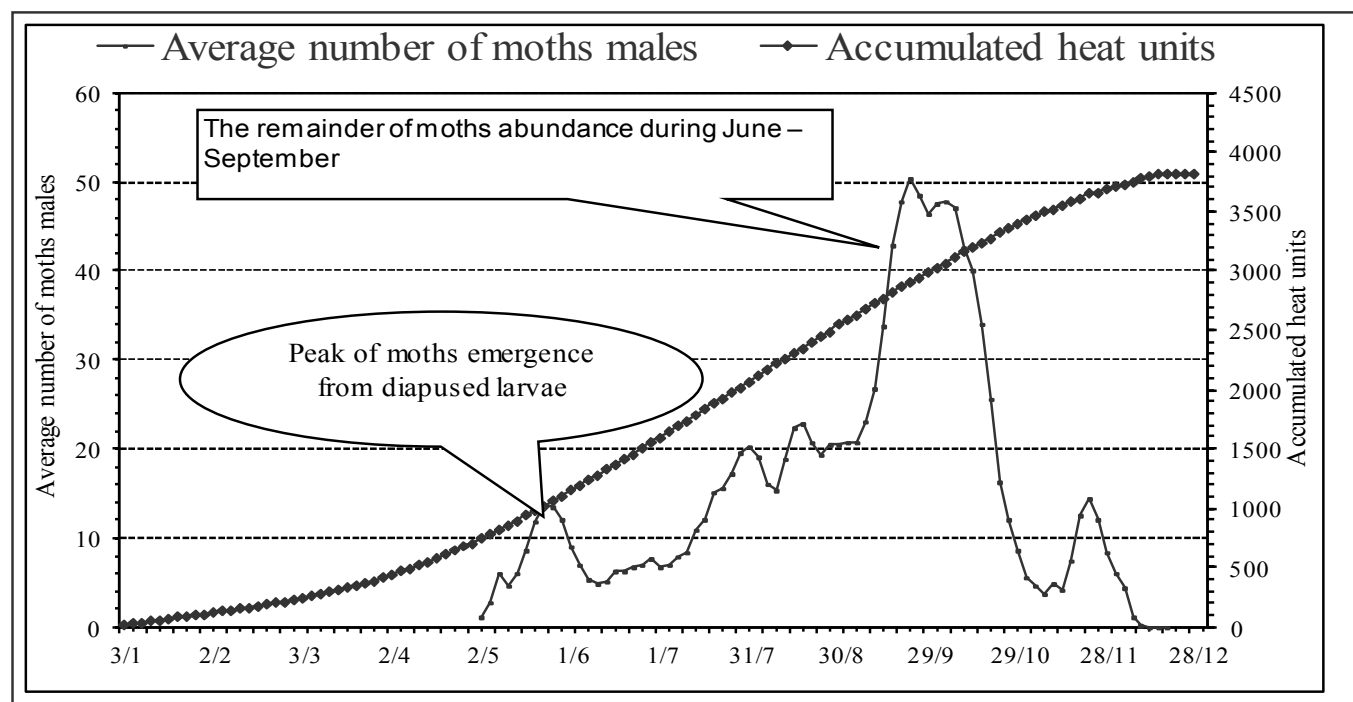

Fig. 1. Average number of accumulated heat units and fluctuated of pink bollworm Pectinophora gossypiella (Saund.) moths through 1999-2002 cotton seasons

Figure (2) shows moth's emergence, in the first peak, reveal first cotton receptors (squares) and its relationship with five different sowing dates, that started from March,10 to April,30; 10 days interval. The first susceptible squares in the first sowing date were occurred before the peak of PBW moth's emergence from diapaused larvae. As a result, fruiting structures ${ }_{\perp}$ (which is the target for PBW infestation $\left.{ }_{L}\right)$ will be subjected to attack by overwintering PBW population for long period of time. Whenever, delayed sowing date (second, third, fourth and fifth) fruiting structures will be subjected to be attacked by first peak of moth's emergence for short period of time. As long as ${ }_{\bar{I}}$ the sowing date was late, the receptor's reveal would be late.

So, we can determine that the suitable sowing date which avoids as much as possible the moths emergence peak from diapaused larvae. That led to reduction in the square infestation, consequently, caused reduction in the boll infestation, that cause increase in crop yield and reduction in the cost of pink bollworm control. 


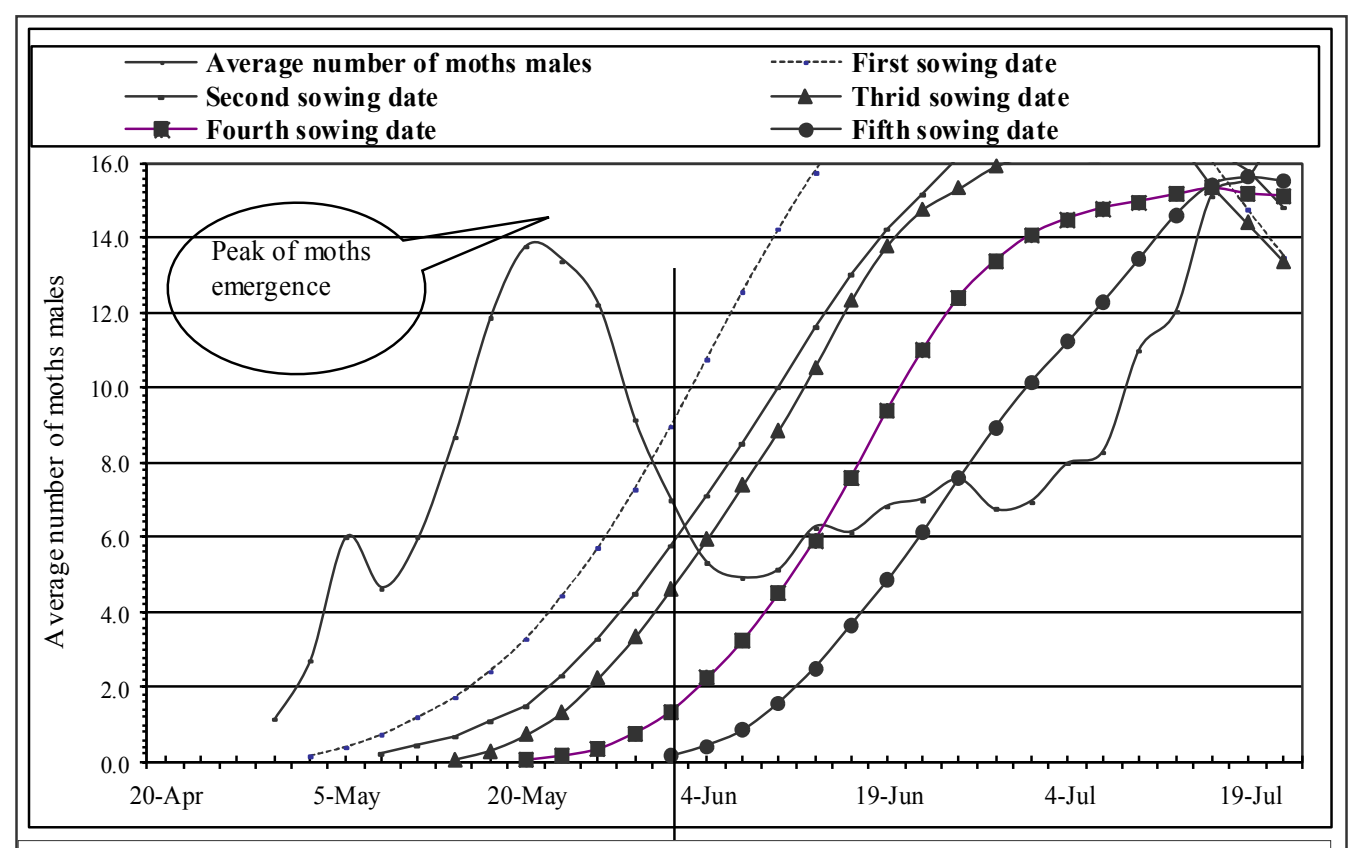

Fig. 2. Peak of male moths which emerged from overwintering pink bollworm diapaused larvae and its relationship to the first receptor (squares) during the five sowing dates started from March,10 to April,30, 10 days interval through 1999-2002 cotton seasons.

Figure (3) shows the average number of AcHU's through the study periods 1999-2002 years and the predicted during 2025, 2050, 2075, and 2100 years. The AcHU's increased gradually to the end of December and in the predicted, the four years. The AcHU's has tended to increase in the predicted years, 2025, 2050, 2075, and 2100 than the current study one, 1999-2002. It was recorded 3814, 4071, 4250, 4403 and 4529 units from the $1^{\text {st }}$ January until the end of December for the current and predicted years, respectively. It increased in the predicted years than the current study periods with 257, 436, 589 and 715 units, respectively (Table 2). These increases of AcHU's will be expected to affect on all environmental components biotic factors, animals, plants.... etc. 


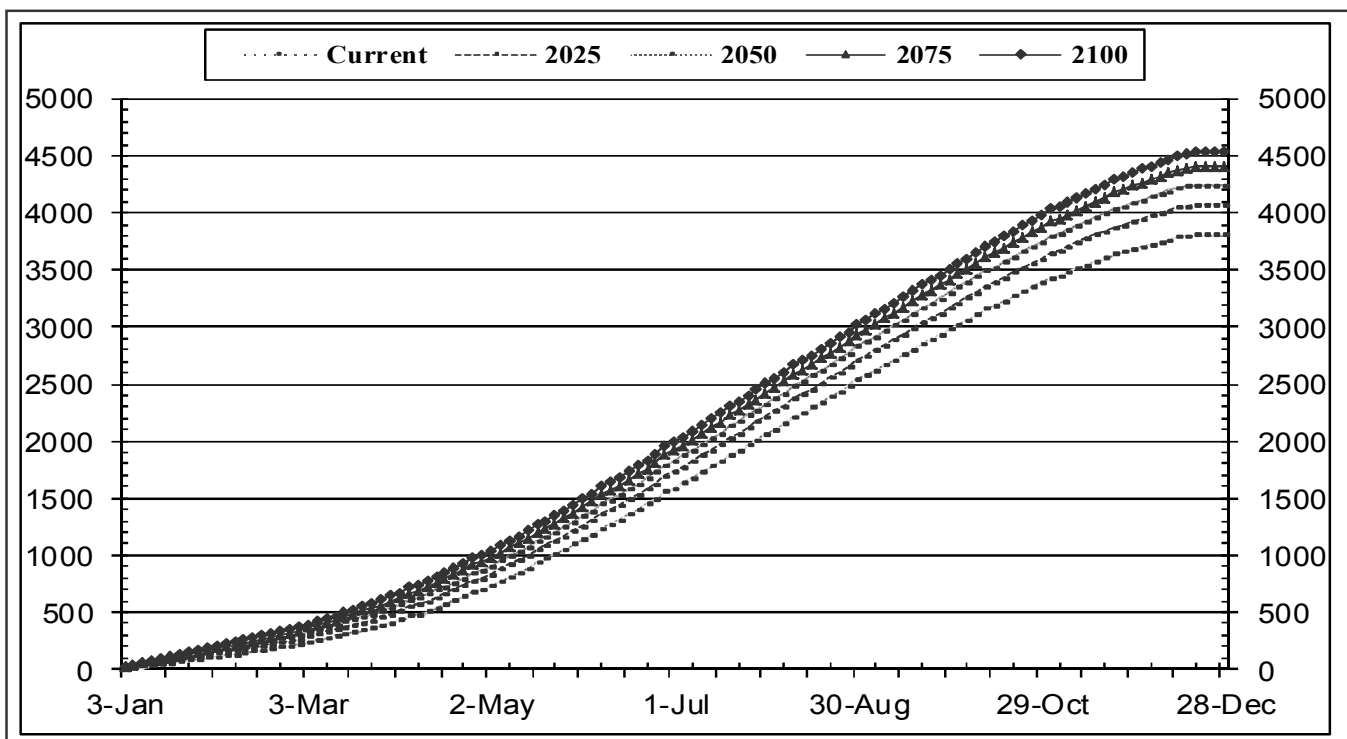

Fig. 3. Average number of accumulated heat units through the study periods of 1999-2002 and the predicted during 2025, 2050, 2075, and 2100 years

Table 2. Average numbers of accumulated heat units through the study seasons of 1999-2002 and the predicted during 2025, 2050, 2075, and 2100 seasons

\begin{tabular}{|c|c|c|}
\hline Seasons & AcHU's & Increasing \\
\hline $1999-2002$ & 3814 & - \\
\hline 2025 & 4072 & 258 \\
\hline 2050 & 4251 & 437 \\
\hline 2075 & 4404 & 590 \\
\hline 2100 & 4529 & 715 \\
\hline
\end{tabular}

It's clearly obvious that the peak of male moth's emergence, from the diapause larvae that temperature dependant from the first of January, occurred through the study seasons, 1999-2002, at the last third of May. Whereas, male moth's peak occurred early in the predicted seasons, 2025, 2050, 2075, and 2100, the occurrence of male moth's peak occurred early, it had been affected by increasing the air temperature, consequently AcHU's The peak of moth's emergence at the predicted season of 2025 occurred at the second third of May, at the first third of May for 2050 season, at the first three days of May for 2075 season and at the last third of April for 2100 season (Fig. 4). 


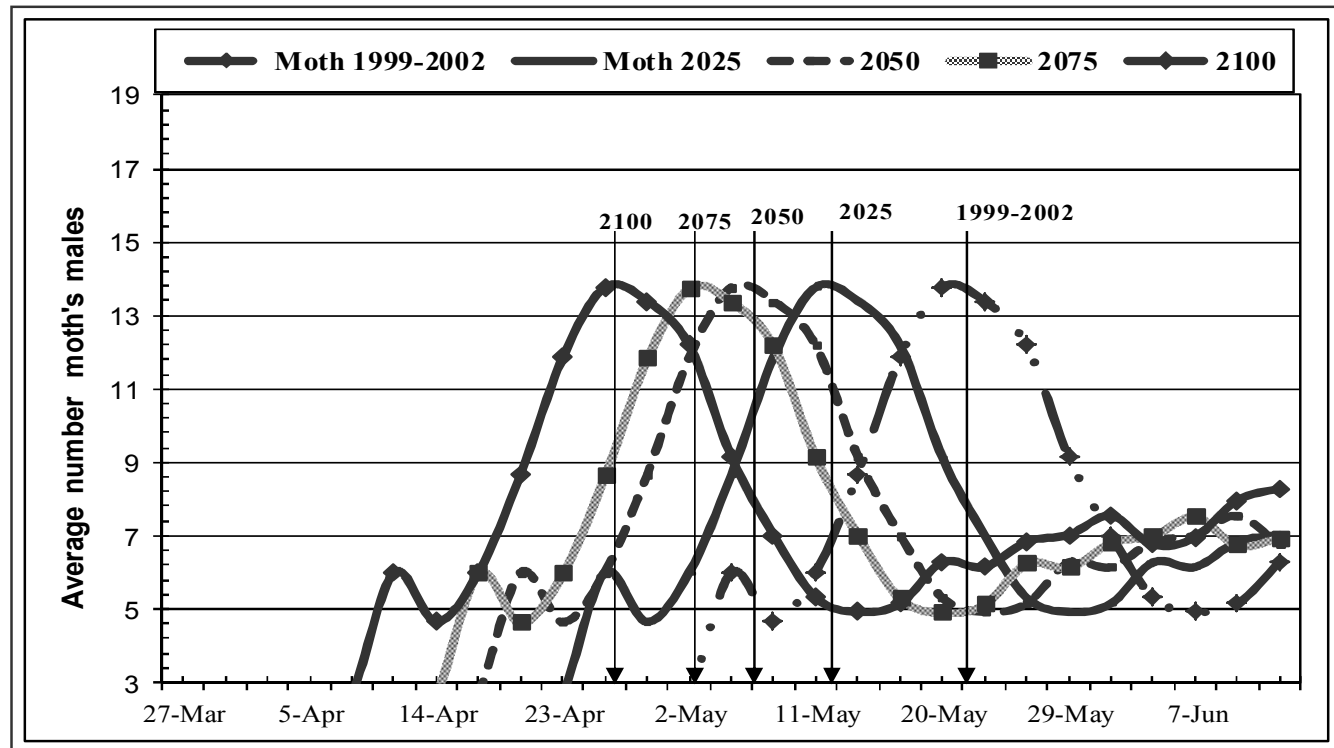

Fig. 4. Peak of moth's emergence, from the diapause larvae, occurred through the study seasons at the last third of May1999-2002 seasons and in the predicted seasons.

Datum of the observed of Julian days and average number of AcHU's (from fixed date Jan., $1^{\text {st }}$ ) required for the five cotton sowing dates on the four cotton seasons (1999-2002), and the expected of Julian days in 2025, 2050, 2075 and 2100 are shown in Table (3). Julian days for the five sowing dates were 74, 84, 95, 105 and 115 days with average $94.6 \pm 16.3$ days and average AcHU's were $285 \pm 37$, $338 \pm 54,422 \pm 70,521 \pm 62$ and $623 \pm 68$ units, respectively with the general average $438 \pm 136.5$ unit. According to the average of AcHU's in the observed, 1999-2002 seasons, the physiological time required for occurrence of the phenomena in the expected of Julian days on 2025 cotton season for the five sowing dates were occurred early, that ranged between 63 and 105 days by general average $83.2 \pm 16.9$ days. The reduction in days percentages were less than the observed with 14.9, 15.5, $12.6,10.5$ and $8.7 \%$, respectively. In 2050 , earliness in the five sowing dates was larger than on 2025 season since the expected of Julian days was with the general average by $77 \pm 16.3$ days where it was ranged between 58 and 98 days. Also, the reduction in days percentages were 21.6, 22.6, 20.0, 16.2 and $14.8 \%$, respectively. Earliness and increasing in the percent reduction continued in 2075 and 2100 cotton season with general average of Julian days by $71.6 \pm 16.5$ and $67.4 \pm 16.5$ days, respectively. In over the four expected cotton seasons comparing to the four cotton seasons of 1999-2002, the physiological time required for occurrence of the phenomena of Julian days for the first cotton sowing dates was the lowest while the fifth one was in Table (3) largest. The periods in days required for the expected four 
cotton seasons were less than in the observed. The periods required for the expected on 2025 over the five sowing dates was the larger than in 2100 one, the period in days decreased gradually from 2025 to 2100 cotton seasons.

Table 3. Comparing the number of days from Jan., $1^{\text {st }}$ required for the five cotton sowing dates during 1999-2002 seasons with the predicted in 2025, 2050, 2075 , and 2100 cotton seasons

\begin{tabular}{|c|c|c|c|c|c|c|c|c|c|c|c|}
\hline \multicolumn{4}{|c|}{$\begin{array}{l}{ }^{1} \text { Observed of number of days and } \\
\text { AcHU during } 1999-2002 \text { seasons }\end{array}$} & \multicolumn{8}{|c|}{ number of days in predicted cotton season } \\
\hline \multicolumn{2}{|c|}{ Sowing Dates } & \multicolumn{2}{|c|}{$\mathrm{AcHU}$} & \multicolumn{2}{|c|}{2025} & \multicolumn{2}{|c|}{2050} & \multicolumn{2}{|c|}{2075} & \multicolumn{2}{|c|}{2100} \\
\hline $\begin{array}{l}\text { Sowing } \\
\text { date }\end{array}$ & $\begin{array}{l}\text { Julian } \\
\text { days }\end{array}$ & Average & Sd* & $\begin{array}{l}\text { Julian } \\
\text { days }\end{array}$ & $\begin{array}{l}{ }^{2} \text { Red. } \\
\% \text { in } \\
\text { days }\end{array}$ & $\begin{array}{l}\text { Julian } \\
\text { days }\end{array}$ & $\begin{array}{l}\text { Red. } \\
\% \text { in } \\
\text { days }\end{array}$ & $\begin{array}{l}\text { Julian } \\
\text { days }\end{array}$ & $\begin{array}{l}\text { Red. } \\
\% \\
\text { in } \\
\text { days }\end{array}$ & $\begin{array}{l}\text { Julian } \\
\text { days }\end{array}$ & $\begin{array}{l}\text { Red. } \\
\% \text { in } \\
\text { days }\end{array}$ \\
\hline $1^{\text {st }}$ & 74 & 285 & 37 & 63 & 14.9 & 58 & 21.6 & 52 & 29.7 & 48 & 35.1 \\
\hline $2^{\text {nd }}$ & 84 & 338 & 54 & 71 & 15.5 & 65 & 22.6 & 60 & 28.6 & 56 & 33.3 \\
\hline $3^{\text {rd }}$ & 95 & 422 & 70 & 83 & 12.6 & 76 & 20.0 & 71 & 25.3 & 66 & 30.5 \\
\hline $4^{\text {th }}$ & 105 & 521 & 62 & 94 & 10.5 & 88 & 16.2 & 82 & 21.9 & 78 & 25.7 \\
\hline $5^{\text {th }}$ & 115 & 623 & 68 & 105 & 8.7 & 98 & 14.8 & 93 & 19.1 & 89 & 22.6 \\
\hline $\begin{array}{l}\text { General } \\
\text { average }\end{array}$ & 94.6 & 438 & & 83.2 & & 77 & & 71.6 & & 67.4 & \\
\hline Sd & 16.3 & 136.5 & & 16.9 & & 16.3 & & 16.5 & & 16.5 & \\
\hline \multicolumn{12}{|c|}{$\begin{array}{c}{ }^{1} \text { Observed: Number of days and average number of accumulated heat units(AcHU) from Jan. }{ }^{\text {st }} \\
\text { occurred for the five sowing dates during } 1999-2002 \text { cotton seasons },{ }^{2} \text { Reduction percentages in days } \\
\text { than observed of the five sowing dates during } 1999-2002=\text { Julian days ((Observed -Predicted)/ } \\
\text { Observed)*100 and }{ }^{3} \text { Sd standard deviation }\end{array}$} \\
\hline
\end{tabular}

Table (4) show that over the five sowing dates, Julian days were ranged between 74 day at the first sowing date and 115 day at the fifth one with range 41 day by 10 days intervals between the five sowing dates and the duration in days and AcHU's for the phenomenon occurrence of 50 percent of plants carrying cotton fruit structures was calculated from sowing dates. The duration in days, as the average to the four cotton seasons (1999-2002), were ranged between 57.0 \pm 4.1 and $41.4 \pm 0.9$ days with rang 15.6 days. Whereas, the AcHU's ranged between 524 and 533 unit with range 9 units, more accurately than days. The same phenomenon at the expected seasons of 2025 cotton seasons, the duration ranged between 53 and 39 days with range 14 days compared to observed 1999-2002, with compensation periods ranged between 4.0 and 2.4days over the five sowing dates. In 2050 cotton season, days reduced by 7 to 3.4 days over the five sowing dates since the duration ranged between 50 and 38 days. The reduction in days continued on 2075 and 2100 cotton seasons by 8.0 to 4.4 and 9.0 to 4.4 days at the same cultivated dates in predicted 2075 and 2100 cotton seasons, respectively. The first sowing date of cultivation had been highly reduction over the expected cotton seasons but the fifth was lowest one. The period in days, required for occurring 50 percent of cotton plants carried fruit structures, decreased at the expected years. The largest reduction in days was 2100 cotton season. The compensation from observed to 2100 was 9 days at the 
first sowing date while reduced to 4.4 days at the fifth one. The highest compensation was found on the first sowing date, whereas the lowest at the fifth one. The average days required to the occurrence of the same phenomenon for the first sowing date was $57.0 \pm 4.1$ days in the observed compared to 48 days for the expected 2100 season, whereas at the fifth one was $41.4 \pm 0.9$ days in the observed compared to 37.0 days for the expected 2100 season. Generally, the physiological time required for occurrence of the phenomena was decreased by 9.0 to 4.4 days over the five sowing dates at 2100 season, it cleared that the cotton plant can get the heat unit required in short time.

Table 4. Comparing the observed averages number of days from the sowing dates needed for the occurrence of 50 percent of cotton plants carrying fruits with the predicted ones in 2025, 2050, 2075, and 2100 cotton seasons.

\begin{tabular}{|c|c|c|c|c|c|c|c|c|c|c|c|c|c|}
\hline \multirow{2}{*}{\multicolumn{2}{|c|}{ Sowing Date }} & \multicolumn{4}{|c|}{$\begin{array}{l}{ }^{1} \text { Observed periods and } \\
\text { AcHU during } 1999-2002 \\
\text { seasons }\end{array}$} & \multicolumn{8}{|c|}{ Predicted cotton seasons } \\
\hline & & \multicolumn{2}{|c|}{ Days } & \multicolumn{2}{|c|}{$\mathrm{AcHU}$} & \multicolumn{2}{|c|}{2025} & \multicolumn{2}{|c|}{2050} & \multicolumn{2}{|c|}{2075} & \multicolumn{2}{|c|}{2100} \\
\hline $\begin{array}{l}\text { Sowing } \\
\text { date }\end{array}$ & $\begin{array}{c}\text { Julian } \\
\text { days }\end{array}$ & $\begin{array}{c}\text { Aver } \\
\text { age }\end{array}$ & $\mathrm{Sd}^{3}$ & $\begin{array}{l}\text { Aver } \\
\text { age }\end{array}$ & Sd & Days & ${ }^{2} \mathrm{Com}$ & Days & Com & Days & Com & Days & Com \\
\hline $1^{\text {st }}$ & 74 & 57.0 & 4.1 & 525 & 24 & 53 & 4.0 & 50 & 7.0 & 49 & 8.0 & 48 & 9.0 \\
\hline $2^{\text {nd }}$ & 84 & 51.6 & 3.3 & 528 & 9 & 48 & 3.6 & 46 & 5.6 & 45 & 6.6 & 44 & 7.6 \\
\hline $3^{\text {rd }}$. & 95 & 47.6 & 2.3 & 533 & 17 & 45 & 2.6 & 43 & 4.6 & 42 & 5.6 & 41 & 6.6 \\
\hline $4^{\text {th }}$. & 105 & 44.6 & 2.4 & 530 & 28 & 41 & 3.6 & 40 & 4.6 & 39 & 5.6 & 38 & 6.6 \\
\hline $5^{\text {th }}$ & 115 & 41.4 & 0.9 & 524 & 25 & 39 & 2.4 & 38 & 3.4 & 37 & 4.4 & 37 & 4.4 \\
\hline Range & 41 & 15.6 & & 9 & & 14 & & 12 & & 12 & & 11 & \\
\hline
\end{tabular}

Table 5. Comparing the observed averages number of days from the sowing dates needed for occur the green cotton bolls preferred for infestation with predicted in 2025, 2050, 2075, and 2100 cotton seasons.

\begin{tabular}{|c|c|c|c|c|c|c|c|c|c|c|c|c|c|}
\hline \multirow{2}{*}{\multicolumn{2}{|c|}{ Sawing Date }} & \multicolumn{4}{|c|}{$\begin{array}{l}{ }^{1} \text { Observed periods and AcHU } \\
\text { during } 1999-2002 \text { seasons }\end{array}$} & \multicolumn{8}{|c|}{ Predicted cotton seasons } \\
\hline & & \multicolumn{2}{|c|}{ days } & \multicolumn{2}{|c|}{ AcHU } & \multicolumn{2}{|c|}{2025} & \multicolumn{2}{|c|}{2050} & \multicolumn{2}{|c|}{2075} & \multicolumn{2}{|c|}{2100} \\
\hline $\begin{array}{l}\text { Sawing } \\
\text { Date }\end{array}$ & $\begin{array}{c}\text { Julian } \\
\text { days }\end{array}$ & $\begin{array}{l}\text { Aver } \\
\text { age }\end{array}$ & Sd & $\begin{array}{l}\text { Aver } \\
\text { age }\end{array}$ & $\mathrm{Sd}^{3}$ & days & ${ }^{2}$ Com. & days & Com. & days & Com. & days & Com. \\
\hline $1^{\text {st }}$ & 74 & 106.6 & 3.8 & 1222 & 8 & 100 & 6.6 & 97 & 9.6 & 95 & 11.6 & 93 & 13.6 \\
\hline $2^{\text {nd }}$. & 84 & 101.4 & 3.6 & 1241 & 26 & 96 & 5.4 & 93 & 8.4 & 91 & 10.4 & 89 & 12.4 \\
\hline $3^{\text {rd }}$. & 95 & 96.0 & 2.6 & 1243 & 39 & 91 & 5.0 & 89 & 7.0 & 87 & 9.0 & 85 & 11.0 \\
\hline $4^{\text {th }}$. & 105 & 92.6 & 2.9 & 1248 & 35 & 87 & 5.6 & 85 & 7.6 & 83 & 9.6 & 82 & 10.6 \\
\hline $5^{\text {th }}$. & 115 & 88.4 & 2.6 & 1248 & 35 & 84 & 4.4 & 82 & 6.4 & 75 & 13.4 & 80 & 8.4 \\
\hline \multicolumn{14}{|c|}{$\begin{array}{l}{ }^{1} \text { Observed: average umber of days and accumulated heat units(AcHU) from the five sowing dates during 1999-2002 cotton } \\
\text { seasons, }{ }^{2} \text { Com: Compensation is the period which the plant can save than observed period during 1999-2002 seasons and }{ }^{3} \mathrm{Sd} \text { : } \\
\text { standard deviation }\end{array}$} \\
\hline
\end{tabular}


Data in Table (5) is clarify a comparison between the averages of days, required to occur green cotton bolls preferred for infestation with PBW larvae in 19992002 cotton seasons and which will be expected in 2025, 2050, 2075 and 2100 cotton seasons, calculated from the five sowing dates. Period in days for the previous phenomenon in 2025 cotton season will be ranged between 100 and 84 days comparing with average days observed of 1999-2002 which ranged between $106.6 \pm 3.8$ and $88.4 \pm 2.6$ days through the five sowing dates. In 2050 cotton seasons, days reduced by 9.6 days at the first sowing dates that decreased gradually until reached to 6.4 days at the fifth one. The reduction continued in 2075 and 2100 cotton seasons by 11.6 and 13.6 days at the first cultivated dates and the same trend in the reduction continued to the fifth one with 13.4 and 8.4 days, respectively. The first dates of cultivation had been highly reduction but the latest was lowest one. The periods required for occurring green cotton bolls preferred for infestation with PBW decreased at the previous predicted years where the largest reduction was in 2100 cotton season. The physiological time required for occurrence of the phenomenon was decreased over the five sowing dates at 2100 season, it cleared that the cotton plant can get the heat unit required in short time.

\section{DISCUSSION}

The impact of climate changes on Julian days, the periods in days required for the expected four cotton seasons were less than in the observed that decreased gradually from 2025 to 2100 cotton seasons. The duration required for appearance of cotton fruit structures, at the first sowing date, the time from sowing date to the occurrence of the first receptor decreased gradually from 57 days, in the current seasons, to 48 days, in 2100 cotton season. For the other sowing dates, the reduction increased which reaching 37 day at the five sowing date. Also, the time required for occurrence of green cotton bolls, which consider the preferred site of pink bollworm infestation, take the same trend as the previous stage (Tables 3-5). This reduction in durations attributed mainly to the increase of temperature which ranged between $0.9^{\circ} \mathrm{C}$ and $4^{\circ} \mathrm{C}$ (Table1), consequently, increase of the accumulated heat unit. On the other hand, temperature increase will affect the key cotton pest, pink bollworm, by the reduction of the period required for the peak of emerged moths and increase number of its generations. Because, the emergence of pink bollworm moths were closely related to the accumulated heat unit from fixed date, Jan, 1 . While the occurring of cotton receptors, squares or green bolls, closely related to sowing dates. Gutierrez, et al. (2006) mentioned that the range of the pink bollworm is limited worldwide by winter frost; hence the predicted milder winters would increase its range northward. Outbreaks of pink bollworm are predicted to be more frequent and severe. The range of pink bollworm on cotton would increase into formerly inhospitable areas of the San Joaquin Valley, and their damage would increase in the current range. Kádár and Szentkirályi (1997) found that consequence of warming is the northward expansion and higher immigration rates of various insect species from the 
Mediterranean, becoming invasive pests due to their rapid spreading in the Carpathian Basin. The cotton bollworm ( $H$. armigera) is a good example. Before the last decade of the $20^{\text {th }}$ century, this migrating moth was recorded rarely, only in low numbers, mainly during hot and dry periods. However in severe drought seasons of the early nineties, after an extensive immigration, $H$. armigera became established. And since, 1993 became one of the most serious agricultural pests with countrywide outbreaks in 1995-96 and 2003 in Hungary. At the northern extremity of its range, this species generally occurs at relatively low population densities and it does not usually overwinters. If however, as a result of global warming, overwintering occurred more frequently, the pest status of this species would increase dramatically (Dosdall 1994).

The model determines the planting and harvest dates each year at all locations. Cotton is assumed to germinate when the 10 days average soil temperatures at 6-in. depth rises above $15^{\circ} \mathrm{C}$, and to stop growing in the fall when 10 days average minimum night temperature falls below $16^{\circ} \mathrm{C}$. (Gutierrez, et al. 2006)

\section{REFERENCES}

1. Abou-Zeid, H. M.; A. Hussein.; M. I. Zaiton and K.K. Abdel-Malak. 1989. Studies on planting cotton to stand under different planting dates. Minia J. Agric. Res. \& Dev. 11(2): 709-723.

2. Balls, W.L. 1919. The cotton plant in Egypt. MacMillan and Co., London. p. 202.

3. P.W. Barnes, P.W. Jordan, W.G. Gold Flint S.D., M.M. Caldwell 1988.Competition, morphology, and canopy structure in wheat (Triticum aestivum L.) and wild oat (Avena fatua L.) exposed to enhanced ultraviolet-B radiation. Func. Ecol., 2: 319-330.

4. Battisti, A. ; M. Sastny; S. Netherer; C. Robinet; A. Schopf; A. Roques and S. Larsson. 2005. Expansion of geographic range in the pine processionary moth caused by increased winter temperatures. Ecological Applications, 15(6): 20842096.

5. Burke, J.J. and D.F. Wanjura. 2009. Plant responses to temperature extremes. pp. 123-128. In: J.M. Stewart, D.M. Oosterhuis, J.J. Heitholt and J.R. Mauney (eds.) Physiology of Cotton. Springer, New York.

6. Dosdall, L. M. 1994. Evidence for successful overwintering of diamondback moth, Plutella xylostella (L.) (Lepidoptera: Plutellidae), in Alberta. Cand. Entomol., 126: 183-185.

7. Eissa, A.M.; F.H. Abdalla; E.M Shalaby and K.K.I.A. Abdel-Malak. 1989. Effect of planting dates and distance between hills on growth and earliness of cotton. Assuit J. Agric. Sci., 20(2): 291-302.

8. Gutierrez, A. P., C. K. Ellis and R. Ghezelbash. 2006. Climatic limits of pink bollworm in Arizona and California: Effects of climate warming." (submitted) Acta Oecologica, 30: 353-364. 
9. Gutierrez, A. P.; L. Ponti, C. K. Ellis and T. D'oultremont. 2006. Analysis of climate effects on agricultural systems. A Report From: California Climate Change Center, University of California, Berkeley.

10. Hennebry, T.J. and S.E. Naranjo. 1998. Integrated management approaches for pink bollworm in the Southwestern United States. Integrated Pest Management Rev., 3: 31-52.

11. Kádár, F. and F. Szentkirályi, 1997. Effects of climatic variations on long-term fluctuation patterns of ground beetles (Coleoptera, Carabidae) collected by light trapping in Hungary. Acta Phytopathologica et Entomologica Hungarica, 32 , 1/2 pp. $185-203$

12. Morrison, J.I. and M.D. Morecroft. 2006. Plant growth and climate change. New York, Wiley-Blackwell, 232p.

13. Parry, M. L.; C. Rosenzweig; A. Iglesias; M. Livermore, G. Fischer, 2004. Effects of climate change on global food production under SRES emissions and socioeconomic scenarios. Global Environmental Change 14: 1 pp. 53-67.

14. Parsons, M. S. and P. Davey. 2007. The rise of the Scarce bordered straw Helicoverpa armigera (Hübner) (Lep.: Noctuidae). Entomologist's Record, 119, 185-192.

15. Reddy, V.R.; D.N. Baker and H.F. Hodges. 1991. Temperature effect on cotton canopy growth, photosynthesis and respiration. Agron. J. 83:699-704.

16. Reddy, K.R.; Hodges, H.F. and McKinion, J.M. 1997. Crop modeling and applications: a cotton example. Adv Agron 59:225-290.

17. Reddy, K. R.; R. D. Prashant; O. M. Linda; Y. L. B. Mariquita; F. H. Harry; G. R. Alec and G. K. Vijaya. 2002. Simulating the impacts of climate change on cotton production in the Mississippi Delta. Clim. Res., 22: 271-281.

18. Sawires, E. M. S. 1976. Effect of planting dates, plant density and number of irrigation on growth, yield and fiber properties of cotton. M. Sc. Thesis, Fac. Agric. Ain Shams Univ.

19. Seaver, D.; J. Strand and A.J. Strawn. 1990. DDU degree-day utility users guide version 2.0 Univ. of California Division of agriculture and natural Resources UCIPM Publication 9. University of California Integrated Pest Management Program, University of California, Davis.

20. Ungerer, M.J.; M.P. Ayres and M.J. Lombardero. 1999. Climate and the northern distribution limits of Dendroctonus frontalis Zimmermann (Coleoptera:Scolytidae). J. Biogeography, 26(6): 1133-1145.

21. Venette, R. C. and W. D. Hutchison. 1999. Assessing the risk of establishment by pink bollworm (Lepidoptera: Gelechiidae) in the southeastern United States. Environ. Entomol., 28: 3, pp. 445-455.

22. Veteli, T.O.; A. Lahtinen; T. Repo; P. Niemelä and M. Varama. 2005.Geographic variation in winter freezing susceptibility in the eggs of the European pine sawfly (Neodiprion sertifer). Agric. \& Forest Entomol. 120. 


\title{
تأثثير التغيرات المناخية علي نمط نمو القطن وعلاقتة بألأصابة

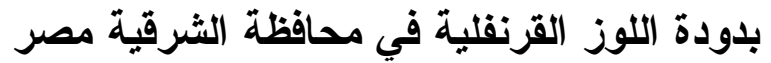

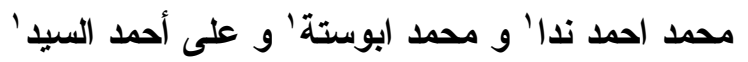

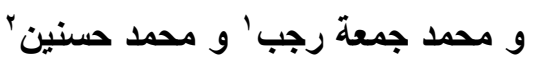 \\ - - معرد بحوث وقاية النباتات مركز البحوث الزراعية الدقي الجيزة مصر

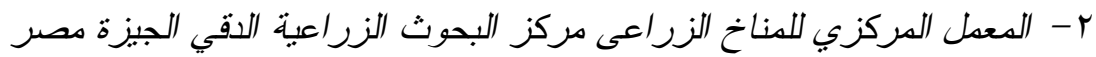

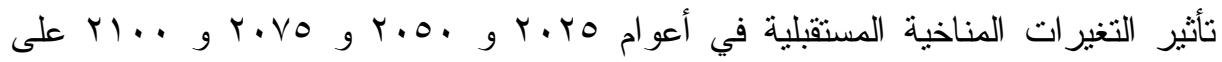

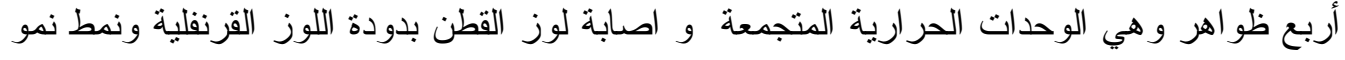

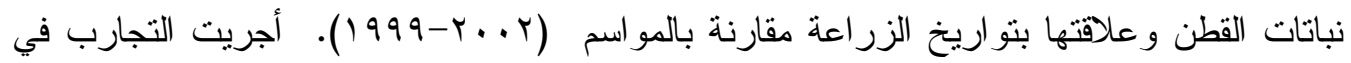

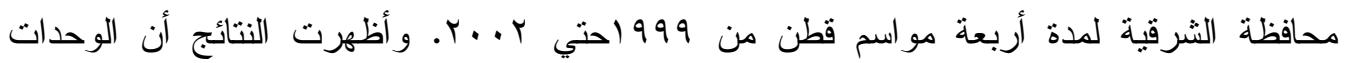

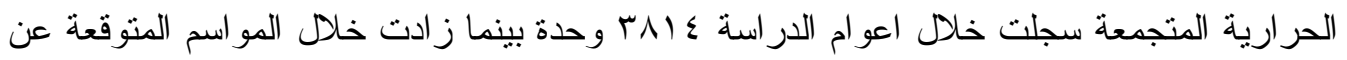

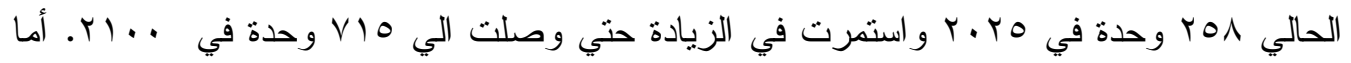

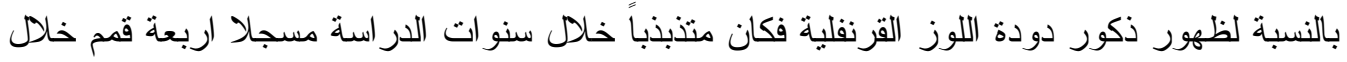

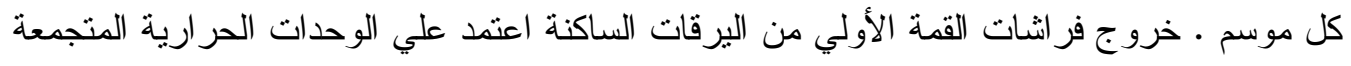

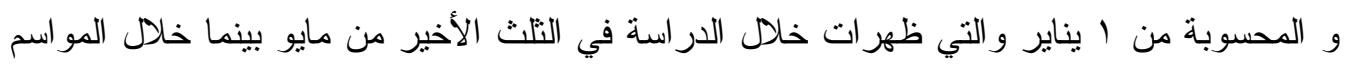

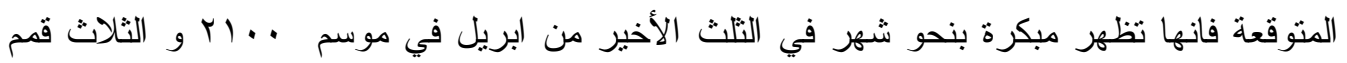

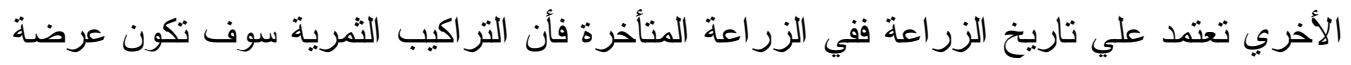

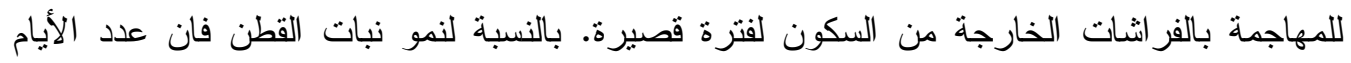
اللازمة لظهور 0\% من نباتات القطن تحمل تز اكيب ثمرية وظهور اللوز الأخضر القابل للاصابة

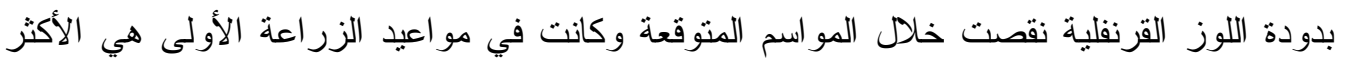

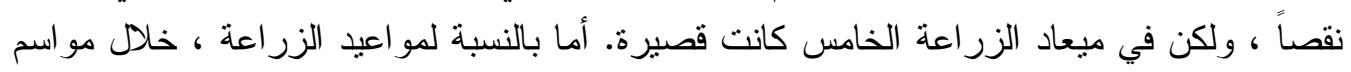

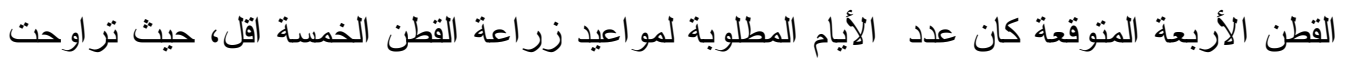

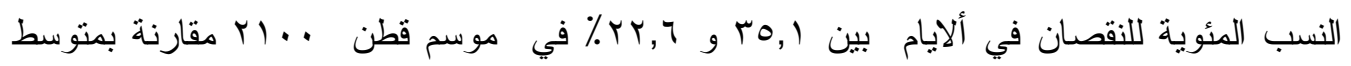

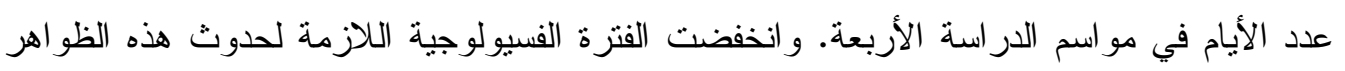

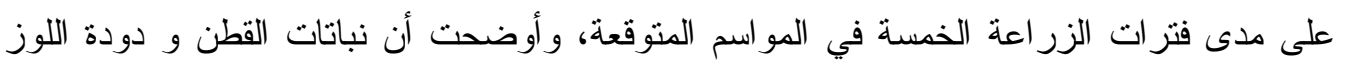

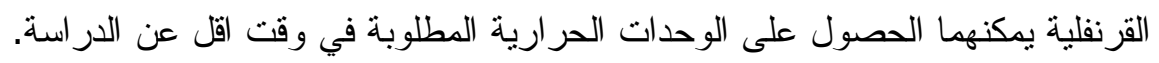

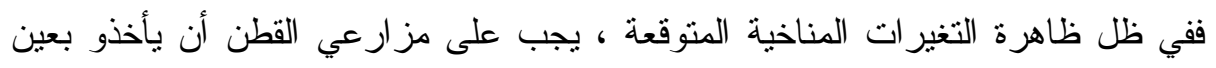

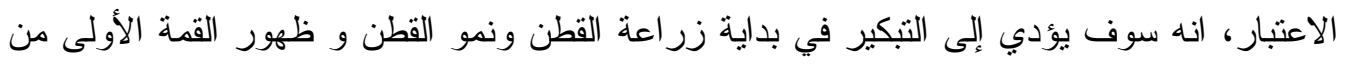

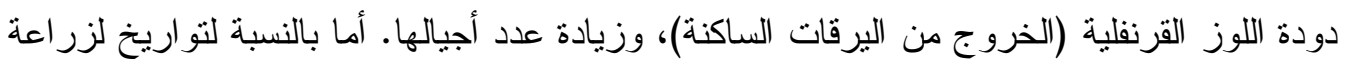

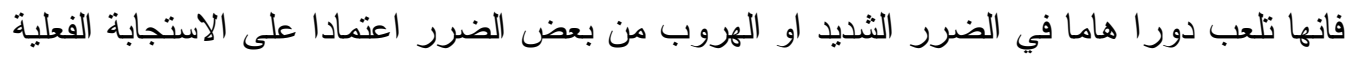

